\title{
WKLAD ŚRODOWISKA TARNOWSKIEGO W BADANIA NAD ANTYKIEM CHRZEŚCIJAŃSKIM
}

\section{PATROLOGIA W TARNOWSKIM INSTYTUCIE TEOLOGICZNYM}

Diecezja tarnowska istnieje dopiero od końca XVIII wieku. Instytut Teologiczny (Wyższe Seminarium Duchowne) natomiast, w pełni ukształtowany, powstał przy końcu lat trzydziestych XIX wieku. Program nauczania w tym Instytucie był podobny do tego, jaki obowiązywał na wydziałach teologicznych w całej monarchii austro-węgierskiej. W programach tych patrologia nie występowała jako samodzielny przedmiot, choć była wykładana w ramach historii Kościoła ${ }^{1}$. Tak też musiało być w Instytucie Tarnowskim, choć szczegółowych danych na ten temat nie ma. Znamy wprawdzie wykładowców historii Kościoła, ale żadnych bliższych szczegółów na temat programu ich wykładów nie mamy. Również publikacje tychże profesorów nie pozwalają na określenie tak ich szczegółowych zainteresowań, jak też ich kwalifikacji jako patrologów. Tak było do okresu międzywojennego. Zdarzało się wprawdzie, że patrologia figurowała jako samodzielny przedmiot, ale było to coś okazjonalnego i epizodycznego ${ }^{2}$. Wykładowcą był profesor historii Kościoła, o niezłych kwalifikacjach naukowych, ale akurat z patrologii nie zaznaczył się w sposób znaczący $^{3}$. Tak było do 1933 roku.

Decyzją nowego ordynariusza ks. bpa Franciszka Lisowskiego w 1933 r. wprowadzono do programu wykładów Instytutu Teologicznego odrębny przedmiot - patrologię. Jego wykładowcą został zamianowany historyk Kościoła ks. dr Władysław Węgiel. Miał on uczyć patrologii obok historii Kościoła. Był on świeżo po studiach teologicznych w Rzymie. Patrologia była przedmio-

${ }^{1}$ Istniały nawet specjalne podręczniki do patrologii, które były używane w Galicji. Szerzej zob. R. Banach, Patrologia i patrystyka w Tarnowskim Instytucie Teologicznym 1838-1951, TST $8(1981)$, s. 351.

2 Tak było np. w latach: 1859-1860, 1869-1870. Szerzej zob. Banach, art. cyt., s. 352.

${ }^{3}$ Był nim ks. dr Wawrzyniec Gwiazdoń, który wykładał także prawo kanoniczne. Ówczesny biskup tarnowski mianował go ekspertem na Sobór Watykański I, co dobrze świadczy o jego kwalifikacjach jako teologa. 
tem wykładanym w wymiarze dwóch godzin tygodniowo, na jednym z pierwszych kursów ${ }^{4}$. Nic bliższego jednak nie wiadomo na temat podręcznika czy też programu tych wykładów. W kilka lat później, ks. dr W. Węgiel przygotował skrypt dla studentów, oparty na znanych wcześniej obcojęzycznych podręczni$\mathrm{kach}^{5}$. Jest to o tyle wymowne, że podobnego skryptu nie opracował $\mathrm{z}$ historii Kościoła, której również nauczał ${ }^{6}$. Jakkolwiek wykładowcą historii był jeszcze przez dłuższy czas, to wydaje się, że okres wczesnochrześcijański i patrologia pozostawały szczególnym obiektem jego zainteresowań. Świadczą o tym jego recenzje publikacji patrystycznych, zamieszczane w urzędowym piśmie kurii tarnowskiej „Currendzie”, w których zachęcał księży do „prenumerowania tłumaczeń Ojców Kościoła"7 . Również na prowadzonym przez siebie w latach późniejszych seminarium naukowym podejmował często problematykę Kościoła wczesnochrześcijańskiego, o czym świadczą tematy prac pisanych na tym seminarium.

W 1951 r. wykładowcą patrologii został świeżo doktoryzowany ks. dr Wojciech $\mathrm{Kania}^{8}$. Nowo mianowany wykładowca patrologii okazał się nie tylko nauczycielem tego przedmiotu, ale także wielkim propagatorem Ojców Kościoła. Przez 37 lat (do 1988 r.) zaznajamiał wszystkich przyszłych kapłanów diecezji tarnowskiej z postaciami i nauką Ojców Kościoła, o których przygotował specjalny skrypt Patrologia (ss. 120). Wziąwszy pod uwagę znaczną liczebność alumnów tarnowskiego seminarium można mówić o bardzo licznym kręgu słuchaczy, których ks. profesor Kania zaznajamiał z bliską sobie problematyką. Podstawową metodą tego przekazu były wykłady. Wielką pomocą okazał się później opracowany na podstawie wspomnianego skryptu jego podręcznik Świadkowie Tradycji. Rys patrystyczny ${ }^{9}$. Książka ta doczekała się kilku wydań, stając się cenną pomocą nie tylko dla studentów Instytutu Teologicznego w Tarnowie, ale też dla szerokiego kręgu czytelników w całej Polsce ${ }^{10}$.

${ }^{4}$ Por. Ks. P. Gajda, Sylwetki biograficzne profesorów seminarium duchownego w Tarnowie. Wykładowcy historii Kościoła i patrologii, „Currenda” 109(1959) s. 307.

${ }^{5}$ Por. R. Banach, art. cyt., s. 354.

${ }^{6}$ Korzystał w tym wypadku z podręcznika ks. J. Umińskiego (Historia Kościoła. Podręcznik do szkót akademickich, t. 1-2, Lwów 1933-1934) por. ks. P. Gajda, jw., s. 307.

${ }^{7}$ Por. m.in. jego recenzje: Dr J. Sajdak, Kwintus Septymiusz Florens. Czasy, życie, dzieła, Poznań 1949, „Currenda” 100(1950) s. 32; Św. Jan Chryzostom, O kapłaństwie, tłum. ks. dr Wojciech Kania, Poznań 1949, ,Currenda” 100(1950) 84-85.

${ }^{8}$ Rozprawę doktorską pt. Ideat mówcy kościelnego według św. Jana Chryzostoma, napisaną pod kierunkiem ks. prof. J. Czuja, obronił 13 VI 1946 r. na Wydziale Teologicznym UW, na Wydziale zaś Teologicznym ATK 19 I 1976 r. odbyło się jego kolokwium habilitacyjne na podstawie rozprawy pt. Problematyka pasterska $w$ pismach egzegetycznych św. Jana Chryzostoma $w$ świetle pism wspótczesnej hermeneutyki biblijnej.

9 Został on wydany sumptem Autora w Tarnowie w 1982 roku. Opóźnienie w wydaniu tego podręcznika było w dużej mierze spowodowane obiektywnymi trudnościami wydawniczymi.

${ }^{10}$ Dowodzi tego konieczność wznawiania wydań tej książki, w coraz to większych nakładach. 
Wykłady z patrologii dla wszystkich studentów to tylko jeden ze sposobów propagowania nauki Ojców Kościoła. Od lat pięćdziesiątych prowadzone były w Instytucie Teologicznym seminaria przedmiotowe, w tym także z patrologii. W ramach tych zajęć, w małych grupach, czytano i egzegetowano teksty Ojców Kościoła. Zaczęły też powstawać prace dyplomowe, spośród których kilka z patrologii - zostały obronione jako magisterskie w innych uczelniach teologicznych, mających prawo nadawania tego stopnia. Od końca bowiem lat sześćdziesiątych wprowadzono obowiązek pisania prac dyplomowych, na seminariach prowadzonych przez profesorów tarnowskiego Instytutu. Seminarium z patrologii cieszyło się dużym zainteresowaniem, czego owocem były liczne prace tam powstałe $^{11}$. Wypada przy tym zauważyć, że w ramach seminarium z patrologii można było poznawać nie tylko teksty greckich i łacińskich Ojców Kościoła, ale też niektórych syryjskich, gdyż dla chętnych ks. prof. Kania prowadził lektorat języka syryjskiego, z którego jako pierwszy Polak przełożył i opublikował kilkanaście pism autorów wczesnochrześcijańskich (św. Efrema, Afrahata, Balaja i Teodora z Mopsuestii) ${ }^{12}$ oraz poprowadził kilka prac dyplomowych; jest on autorem ponad 150 publikacji patrystycznych, w tym 9 książek $^{13}$. W uznaniu jego zasług dydaktyczno-naukowych wręczono mu 18 X 1988 r. w Katolickim Uniwersytecie Lubelskim Księgę Pamiątkową („Vox Patrum” t. 12-13) dedykowaną przez patrologów całej Polski. W latach 1978-1980 seminarium patrystyczne obok ks. prof. Kani prowadził również doktoryzowany (1976 r.) w rzymskim Instytucie Patrystycznym „Augustinianum” ks. dr S. Longosz ${ }^{14}$.

W latach osiemdziesiątych prace $\mathrm{z}$ patrologii można było także pisać w ramach drugiego seminarium, prowadzonego przez ks. dr E. Łomnickiego $^{15}$. W ramach tego seminarium powstawały głównie prace o charakterze translatorskim. Od $1988 \mathrm{r}$. seminarium z patrologii zaczął prowadzić następca ks. prof. W. Kani na katedrze, ks. dr A. Żurek ${ }^{16}$, który doktoryzował się

${ }^{11}$ Wykaz pisanych pod jego kierunkiem prac dyplomowych do r. 1987 zob. VoxP 7(1987) z. 12-13, s. 11, n. 16-17.

${ }^{12}$ Por. m.in. Wybrane pieśni i poematy syryjskie, PSP 11, Warszawa 1973; przekład 18 Katechez Teodora z Mopsuestii w druku.

13 Wykaz jego publikacji do r. 1987 zob. VoxP 7(1987) z. 12-13, 27-37.

14 Tytuł jego rozprawy doktorskiej: De auctoritate Traditionis apud Athanasium Alexandrinum. Synthesis Traditionis primi et secundi momenti controversiae arianae (318-362), Romae 1976; wcześniej ukończył w KUL studia filologii klasycznej (magisterium 1970: Inwektywa przeciw panującym u łacinskich pisarzy chrześcijańskich IV wieku. Obelgi Lucyferiusza z Calaris przeciw Konstancjuszowi $w$ świetle tradycji inwektywy starożytnej) i historii Kościoła starożytnego ze specjalizacją w patrologii (licencjat 1971: Problem literackiej spuścizny Ariusza).

${ }_{15}$ Odbył studia specjalistyczne z filologii klasycznej i apologetyki w KUL oraz doktoryzował się na podstawie pracy: Kryteria wiarygodności chrześcijaństwa w ujęciu apologetów starochrześcijańskich, Lublin 1977.

16 Temat rozprawy doktorskiej: Il matrimonio nei sermoni di Cesario di Arles. Ricerca storicoteologica nell' etica coniugale del secolo VI (obrona 5 VI 1985); kolokwium habilitacyjne w $1998 \mathrm{r}$. 
w Instytucie Patrystycznym „Augustinianum” w Rzymie kilka lat wcześniej (1985 r.). W ten sam sposób powiększyła się możliwość pisania prac z patrologii. Wprawdzie na początku lat dziewięćdziesiątych zarówno ks. prof. W. Kania, jak też ks. dr E. Łomnicki zrezygnowali z prowadzenia seminariów i tym samym zaprzestano pisać prace dyplomowe i magisterskie pod ich kierunkiem, ale $\mathrm{z}$ kolei ks. dr S. Sojka ${ }^{17}$ rozpoczął prowadzenie takiego seminarium dla świeckich studiujących w miejscowym Instytucie Teologicznym. Tak więc możliwość pisania prac z patrologii była duża.

Jak już wspomniano, seminarium z patrologii cieszyło się od samego początku znacznym zainteresowaniem. Z całą pewnością duża w tym zasługa ks. prof. W. Kani, który umiał zainteresować tą problematyką wielu studentów. Od chwili, gdy w ramach tego seminarium zaczęły powstawać prace dyplomowe, można to zainteresowanie dokumentować. Ogólnie - wliczając w to także kilka prac o tematyce patrystycznej, powstałych na innych seminariach - w Tarnowie powstało ponad 120 takich prac. Nie oddaje to jednak w pełni ani skali zainteresowania, ani też wkładu środowiska tarnowskiego w propagowanie myśli Ojców Kościoła. Należy do tego dodać również prace, w których problematyka patrystyczna zajmuje znaczące miejsce ${ }^{18}$. Od kilku lat istnieje też możliwość pisania i bronienia prac licencjackich. Jak dotychczas możliwość tę wykorzystały zaledwie dwie osoby.

Instytut Teologiczny w Tarnowie propagował naukę Ojców Kościoła nie tylko w wymiarach przewidzianych dla własnych studentów teologii. Wytworzyła się tam atmosfera sprzyjająca rozwojowi studium patrologii. Złożyło się na to wiele czynników. Jednym $\mathrm{z}$ nich była niewątpliwie życzliwa postawa miejscowego ordynariusza ks. bpa J. Ablewicza. Szacunek, jakim darzył teksty Ojców Kościoła wyraził się m.in. w wysłaniu na studia patrystyczne do Rzymu ks. mgra Stanisława Longosza, który jako pierwszy z Polaków uzyskał (1976 r.) w Instytucie Patrystycznym „Augustinianum” doktorat ,in scientiis patristicis”. Być może ta atmosfera sprawiła, że pod koniec lat siedemdziesiątych nastąpiło zacieśnienie współpracy z PAT-em w Krakowie. Wówczas to z inspiracji ówczesnego abpa krakowskiego ks. kardynała Karola Wojtyły powstała myśl o założeniu w Tarnowie specjalnego Instytutu Patrystycznego. Inicjatywa padła na podatny grunt i spotkała się z życzliwym podejściem ze strony ówczesnego biskupa tarnowskiego, wspomnianego ks. bpa J. Ablewicza. Realizację tej

na Wydziale Teologicznym PAT na podstawie rozprawy pt. Duszpasterz końca epoki patrystycznej. Tożsamość kaptana w świetle „De vita contemplativa” Juliana Pomeriusza.

17 Odbył studia specjalistyczne w KUL z filologii klasycznej (magisterium 1985: „Actio" $i$ „contemplatio” w pismach Grzegorza Wielkiego) i teologii moralnej, z której doktoryzował się w r. 1986 na podstawie pracy pt.: Ideat życia kapłańskiego $w$ świetle pism świętego Grzegorza Wielkiego.

${ }^{18} \mathrm{~W}$ tym kontekście warto tu wspomnieć prace pisane pod kierunkiem ks. dr hab. A. Paciorka z egzegezy Pisma św. Nowego Testamentu. 
inicjatywy bp J. Ablewicz zlecił ks. dr. S. Longoszowi. Desygnowany w sposób dynamiczny zabrał się do organizowania Instytutu. Zadanie jednak nie było łatwe, bo oprócz ogólnej idei, deklaracji dobrych intencji ze strony władz diecezjalnych i nieco własnych doświadczeń, ks. dr Longosz nie dysponował żadnymi innymi środkami. Trzeba było pomyśleć o programie studiów, kadrze, księgozbiorze i bazie materialnej. A wciąż trzeba pamiętać o specyfice tamtych lat i tamtego okresu.

Dzięki sprawności organizacyjnej ks. Longosza pomysł, dość obcy szerszemu środowisku teologicznemu, zaczął przybierać konkretne kształty: powstał projekt statutu, siatka przewidywanych wykładowców i specjalny zakład „Patristicum”, zamówiono kilka zagranicznych podstawowych serii patrystycznych, zaczęto tworzyć specjalistyczny księgozbiór, a opracowane projekty przesłano do Kongregacji d/s Wychowania w Rzymie. Dla przybliżenia nauki Ojców Kościoła ks. bp J. Ablewicz zorganizował kilka akcji propagandowych w postaci diecezjalnych dni katechetycznych czy specjalnych prelekcji patrystycznych $^{19}$, w dniach 19-21 X 1978 r. gościł natomiast zorganizowane przez Sekcję Patrystyczną, Katedry Patrologii ATK i Międzywydziałowy Zakład Badań nad Antykiem Chrześcijańskim KUL ogólnopolskie sympozjum (kongres) poświęcone modlitwie starożytnych chrześcijan ${ }^{20}$, a zakończone uroczystą koncelebrą z elementami starożytnymi w bazylice katedralnej. Pomysł Instytutu nie został jednak zrealizowany i ostatecznie w 1980 r. inicjatywa upad$\mathrm{la}^{21}$. W sensie materialnym pozostał przede wszystkim dość pokaźny księgozbiór i popularyzacja samej patrologii w środowisku tarnowskim. Bez wchodzenia w kwestię zasadności i możliwości realizacji pomysłu Instytutu Patrystycznego można z całą odpowiedzialnością uznać to za bardzo oryginalną inicjatywę.

\section{TARNOWSCY PROMOTORZY OJCÓW KOŚCIOŁA}

Tradycje patrystyczne w Tarnowie to zasługa przede wszystkim działających tu ludzi, których można uważać za promotorów Ojców Kościoła w skali nie tylko diecezji, ale dużo szerszej, tym bardziej, że wielu z nich wykraczało poza to środowisko. Lista osób zasługujących na wspomnienie jest długa, ale ograniczymy się do kilku.

19 Por. S. Longosz, Popularyzacja Ojców Kościota w latach $1979-1980$ na terenie diecezji tarnowskiej, „Currenda” 131(1981) 34-48.

20 Akta tego sympozjum zostały wydane w 18 tomie „Tarnowskich Studiów Teologicznych”, Tarnów 1981, ss. 382.

${ }^{21}$ Szczegółowo na temat tej inicjatywy zob. niżej: S. Longosz, Instytut Patrystyczny w Tarnowie. 
1. Ks. Jan Czuj (1886-1957). Otwiera ją ks. prof. Jan Czuj ${ }^{22}$. Pochodził z chłopskiej rodziny, zamieszkałej w Borzęcinie. Dzięki wrodzonym zdolnościom wyróżniał się już w szkole ludowej, do której uczęszczał w swojej rodzinnej wsi. Zachęcony i wspomagany przez miejscowego nauczyciela kontynuował studia w I gimnazjum w Tarnowie. Gimnazjum to miało dobre tradycje w kształceniu, zwłaszcza klasycznym. W czwartej klasie tegoż gimnazjum wstąpił do Małego Seminarium. Po zdaniu egzaminu maturalnego wstąpił do Wyższego Seminarium Duchownego w Tarnowie i rozpoczął studia teologiczne, które ukończył z dobrym wynikiem, zdradzając już w czasie ich trwania zacięcie do nauki ${ }^{23}$. Po święceniach w 1912 r. rozpoczął pracę jako wikariusz ${ }^{24}$, jednocześnie za zgodą ks. bpa Ordynariusza rozpoczął studia na Wydziale Teologicznym UJ. Nie zaniedbując pracy wikariuszowskiej napisał pod kierunkiem znanego wówczas historyka Kościoła ks. prof. Jana Fijałka pracę doktorską na temat: Kościół a państwo u św. Augustyna ${ }^{25}$. Ostatecznie dyplom doktora teologii w zakresie patrystyki uzyskał w 1916 roku. W tym też czasie publikował w redagowanym przez siebie tygodniku Historię Kościoła w obrazach.

Jak widać, od samego początku swej kariery naukowej zainteresowania ks. J. Czuja koncentrowały się wokół starożytności chrześcijańskiej. Będą one z czasem coraz bardziej jednoznacznie związane z Ojcami Kościoła, choć towarzyszyła temu również bardzo szeroka działalność na innych odcinkach ${ }^{26}$. W 1920 r., z własnej inicjatywy, wyjechał do Rzymu na dwuletnie stypendium na Uniwersytecie Gregoriańskim. Tytuł „magister aggregatus” tego uniwersytetu uzyskał na podstawie rozprawy o hierarchii u św. Augustyna ${ }^{27}$. Wrócił na to samo stanowisko, tj. katechety gimnazjalnego w Brzesku. Wnet jednak zaczął z Brzeska dojeżdżać do Lublina, by tam prowadzić zajęcia z patrologii. Taka sytuacja trwała do 1938 roku. W tym czasie zaczęły się ukazywać jego rozprawy z patrologii ${ }^{28}$, oraz prace translatorskie ${ }^{29}$. Od $1938 \mathrm{r}$. rozpoczął pracę

${ }^{22}$ Zwięzłą biografię ks. J. Czuja oraz jego pełną bibliografię opracował ks. W. Kania w TST 8(1981) 357-363; Stownik Polskich Teologów Katolickich, V, Warszawa 1983, 271-273; EK III, 926-927; Cz. Mazur, Materiaty do bibliografii prac ks. Jana Czuja, SACh 2(1980) 236-243.

${ }^{23}$ Wyrazem tego są jego pierwsze artykuły pisane w ramach pracy seminaryjnego Koła Naukowego św. Ambrożego, które potem ukazały się drukiem w poznańskich „Głosach na czasie" jako pierwsza jego książka, por. W. Kania, art. cyt., s. 358.

${ }^{24}$ Pierwszą jego placówką byla parafia Ciężkowice. W 1914 r. został przeniesiony do tarnowskiej katedry. Wnet też został mianowany redaktorem świeżo powstałego tygodnika „Lud Katolicki”.

25 Kościót a państwo u św. Augustyna, Lwów 1918.

${ }^{26}$ Ks. J. Czuj był aktywnym katechetą, publicystą, działaczem politycznym.

27 W języku polskim praca Hierarchia u św. Augustyna, ukazała się w Lublinie w 1925.

${ }^{28}$ Były to monografie: Pacjan z Barcelony. Studium patrologiczne, Tarnów 1922; Święty Cyprian, biskup-męczennik, Kraków 1927; Chrystusowi bohaterzy, Kraków 1927; Żywot św. Augustyna, Kraków 1928, 1952; Święty Augustyn o Żydach, Kraków 1928; Św. Augustyn, jego mtodość, nawrócenie i udoskonalenie, Kraków 1930; Poglądy świętego Augustyna na wymowę kościelną, Warszawa 1932; Spór św. Augustyna ze św. Hieronimem, Poznań 1934; Święty Cyprian na tle 
w Uniwersytecie Warszawskim, gdzie objął katedrę patrologii i homiletyki. W czasie okupacji często przebywał na terenie diecezji tarnowskiej, gdzie m.in. zachęcał księży do studiowania patrologii ${ }^{30}$. Po wojnie nadal działał w Warszawie, będąc m.in. jednym z organizatorów Akademii Teologii Katolickiej. Zmarł 2 sierpnia 1957 roku w Warszawie, pozostawiając po sobie niekwestionowany dorobek patrologiczny.

2. Ks. Władysław Budzik (1890-1949). Każdy kto zajmuje się patrologią docenia wartość serii „Pisma Ojców Kościoła”. Jednym z tłumaczy tej serii był inny ksiądz diecezji tranowskiej, ks. katecheta Władysław Budzik. Pochodził z rodziny chłopskiej, ale ukończył dobre - to samo co ks. J. Czuj - gimnazjum w Tarnowie. Potem wstąpil do tarnowskiego seminarium duchownego, gdzie został wyświęcony na kapłana w 1915 roku. Tam też zaprzyjaźnił się z ks. J. Czujem ${ }^{31}$. Całe kapłańskie życie był katechetą, $\mathrm{m}$. in. przez wiele lat w Borzęcinie, rodzinnej miejscowości ks. J. Czuja. Według tego ostatniego, ks. W. Budzik ,z tarnowskiego gimnazjum i seminarium duchownego wyniósł solidne podstawy do pracy literacko-naukowej: był zwłaszcza dobrym filologiem"32. Te kwalifikacje, a zapewne też sugestie ks. J. Czuja, skłoniły ks. W. Budzika do podjęcia się pracy thumacza, obok innych inicjatyw autorskich $^{33}$. Przetłumaczył i przygotował do druku Pisma katechetyczne św. Augustyna $^{34}$. Tłumaczenie to spotkało się z życzliwym przyjęciem, skoro po wojnie zostało wydane po raz wtóry. W następnej kolejności przetłumaczył z greckiego i opracował Katechezy Cyryla Jerozolimskiego ${ }^{35}$. Zainteresowanie Ojcami Kościoła owocowało też w innych jego publikacjach ${ }^{36}$.

epoki, Włocławek 1936; Święty Ambroży w świetle swoich listów, Warszawa 1939; Papież Grzegorz Wielki, Warszawa 1948; Święty Hieronim. Żywot - dzieta - charakterystyka, Warszawa 1954; Patrologia, Poznań 1953, 1954.

29 Por. Św. Augustyn, Wyznania, POK 9, 1929; Wiktor z Wity, Historia prześladowania wiary w Afryce, POK 14, Poznań 1930; Laktancjusz, Pisma wybrane, POK 16, Poznań 1933; Leon W., Mowy, POK 17, Poznań 1936; Apologeci greccy II wieku, POK 18, Poznań 1935; Cyprian, Traktaty, POK 19, Poznań 1937; Ambroży, Mowy, POK 21, Poznań 1939; Grzegorz I Wielki, Księga reguty pasterskiej, POK 22, Poznań 1948; Grzegorz I Wielki, Listy, I-IV, Warszawa 1952-1954; Hieronim, Listy, I-III, Warszawa 1952-1954. Przygotował: Metody z Olimpu, Uczta dziesięciu dziewic.

${ }^{30}$ Tak miała się rozpocząć kariera naukowa ks. W. Kani.

${ }^{31}$ Por. Ks. J. Czuj, Ks. Władysław Budzik, „Currenda” 100(1950), s. 131.

32 Tamże.

${ }^{33}$ Był też autorem kilku katechizmów i podręczników do nauki religii.

34 Ukazały się w X tomie POK w Poznaniu 1929, a potem w Warszawie w 1952 roku.

${ }^{35}$ Miały się one ukazać w serii POK, ale w czasie wojny spłonęły.

${ }^{36}$ Opublikował: Katechetyka św. Augustyna a nasze katechizmy, AK 16(1930) t. 26, 153-160. Był autorem recenzji prac i tłumaczeń dokonywanych przez ks. J. Czuja: Żywot św. Augustyna, AK 23(1929), 202-203; Wiktor z Wity, Dzieje prześladowań wandalskich w Afryce, AK 18(1932), 200-201; Laktancjusz, Pisma wybrane, AK 20(1934), 204-205; Apologeci greccy II w., AK 22(1936), 
3. Ks. prof. Wojciech Kania ${ }^{37}$. Przedstawiając wybitne postacie środowiska tarnowskiego, zasłużone dla polskiej patrologii, nie można pominąć ks. prof. dra hab. Wojciecha Kani. Jego zasługi na tym polu są powszechnie znane i co ważniejsze, nadal rosną. W tym miejscu warto przypomnieć, że zainteresowanie Ojcami Kościoła w tym przypadku jest też zasługą ks. J. Czuja. To on właśnie zachęcił w czasie wojny ks. W. Kanię - wówczas młodego wikarego do studiowania patrologii. Z całą pewnością studia te stały się możliwe dzięki dobremu przygotowaniu filologicznemu i osobistym predyspozycjom. Jedno i drugie odegrało też bardzo istotną rolę w przyszłej karierze naukowej. Właśnie prace translatorskie stanowią największą część dorobku ks. prof. dra hab. W. Kani. Tłumaczenia z łaciny, greki i egzotycznego, jak na warunki polskie, języka syryjskiego, zapewniły mu trwałe miejsce w polskiej patrystyce. Obok tego ważna okazała się praca popularyzatorska prowadzona niekiedy w bardzo oryginalny i niekonwencjonalny sposób ${ }^{38}$.

Jako wykładowca patrologii w Instytucie Teologicznym w Tarnowie wytworzył wokół Ojców Kościoła atmosferę na tyle sprzyjającą, że bardzo duża grupa studentów wybierała seminarium $\mathrm{z}$ patrologii $\mathrm{i}$ pisała $\mathrm{z}$ tej dziedziny prace dyplomowe i magisterskie. $\mathrm{Z}$ całą pewnością ta atmosfera wpłynęła, choć trudno to jednoznacznie udokumentować, na to, że stosunkowo duża liczba księży robiących specjalizację podejmowała tematy patrystyczne. Natomiast publikacje o charakterze patrystycznym autorstwa księdza Kani w piśmie urzędowym diecezji tarnowskiej „Currenda” upowszechniły znajomość Ojców Kościoła wśród księży. Publikacje te zaczęły się systematycznie ukazywać od lat pięćdziesiątych i należą z całą pewnością do wyjątkowych w Polsce. Do popularyzacji Ojców Kościoła wykorzystywał wszystkie nadarzające się okazje. Również włączał się aktywnie w działalność polskich patrologów, zwłaszcza w działalność Sekcji Patrystycznej polskich teologów.

4. Inni autorzy. Oprócz tych bardzo znanych autorów, w środowisku tarnowskiem na niwie patrystycznej działali też inni, mniej znani, albo też tacy, którzy Ojcami Kościoła interesowali się, bądź też interesują, w sposób okazjonalny. W perspektywie historycznej należy tu wspomnieć kilka ciekawych przykładów. Już pod koniec ubiegłego wieku profesor dogmatyki ks. J. Tylka (1857-

324-325; Leon W., Kazania wybrane, „Przegląd Katolicki” 14(1936) nr 35, s. 605; zob. też: „Miesięcznik Katechetyczny i Wychowawczy” 16(1927) 467-470; 17(1928) 36. Ks. W. Budzik był też autorem podręczników do nauki religii.

${ }^{37}$ Obszerną prezentację postaci i dorobku ks. prof. dr hab. W. Kani przedstawił ks. S. Longosz, VoxP 7(1987) nr 12-13, 9-37.

${ }^{38}$ Należy tu przede wszystkim wspomnieć popularną serię jego tłumaczeń „Źródła Tradycji” (27 zeszytów), wydawaną kosztem Autora i rozprowadzaną przez niego darmowo. Również oryginalna galeria fundowanych przez niego portretów Ojców Kościoła w kościele Św. Trójcy w Tarnowie nie znajduje konkurencji w tej dziedzinie w Polsce. 
1925) opublikował pracę o Klemensie Aleksandryjskim ${ }^{39}$. W początkach tego stulecia problematyką tą interesowal się biblista ks. prof. P. Stach ${ }^{40}$, a także ks. S. Sroka, który doktoryzował się z tej tematyki w okresie międzywojennym ${ }^{41}$.

W okresie powojennym stosunkowo liczna grupa tarnowskich teologów wyrażała bliższe zainteresowanie patrologią. $\mathrm{Z}$ tą dziedziną były związane prace doktorskie księży: E. Łomnickiego ${ }^{42}$, S. Sojki ${ }^{43}$, R. Kurka ${ }^{44}$, S. Budzi$\mathrm{ka}^{45}, \mathrm{~S}$. Longosza ${ }^{46}$, A. Żurka ${ }^{47}$. W większości tych autorów zainteresowania patrystyczne zaowocowały dalszymi publikacjami z tej dziedziny ${ }^{48}$. Oprócz nich interesujące prace $\mathrm{z}$ tej dziedziny opublikowali m.in. księża: B. Kumor ${ }^{49}$, J. Dudziak ${ }^{50}$, J. Królikowski ${ }^{51}$, A. Paciorek ${ }^{52}$, A. Drożdz ${ }^{53}$. Przy czym, zwła-

${ }^{39}$ Por. J. Tylka, Ztote ksiązeczki, t. 1: Dzieło o życiu i pismach Klemensa Aleksandryjskiego, Tarnów 1892.

${ }^{40}$ Por. Komunizm w pierwotnym chrześcijaństwie a czasy obecne, Lwów 1926 (to samo w odcinkach w „Gazecie Kościelnej” 33(1926); Św. Augustyn w walce z heretykami, Lwów 1930 (to samo w odcinkach w „Gazecie Kościelnej” 37(1930); Najnowsze polskie przekłady dzieł św. Augustyna, PT 11(1930) 531-635; Św. Augustyn jako biblista, PT 11(1930) 414-450; Ostatnie chwile św. Augustyna na ziemi i losy jego relikwii, „Gazeta Kościelna” 37(1930) 429-431; a także 2 recenzje: J. Czuj - Żywot św. Augustyna, Kraków 1928 = „Ruch Teologiczny” 1(1929) 30-31, oraz: T. Sinko - Literatura grecka, III, Kraków 1951 = RBL 5(1952) 179-187.

${ }^{41}$ Por. Ks. S. Sroka, Nauka św. Cypriana o miłosierdziu chrześcijańskim, Tarnów 1939.

42 Por. E. Łomnicki, Kryteria wiarygodności chrześcijaństwa w ujęciu apologetów starochrześcijańskich, Lublin 1977.

${ }^{43}$ Por. S. Sojka, Ideat życia kaptańskiego w świetle pism świętego Grzegorza Wielkiego, Lublin 1986.

44 Por. R. Kurek, Aspetto biblico della spiritualità Pacomiana, Roma 1982.

45 Por. S. Budzik, Doctor pacis. Theologia des Friedens bei Augustinus, Innsbruck 1988.

46 S. Longosz, De auctoritate Traditionis apud Athanasium Alexandrinum (295-373), Roma 1976.

${ }^{47}$ Por. A. Żurek, Matrimonio nei Sermoni di Cesario di Arles, Roma 1985.

48 Głównie na łamach „Vox Patrum” i „Tarnowskich Studiów Teologicznych”.

49 Por. Ks. B. Kumor, Pokuta kościelna w pismach Tertuliana, RTK 4(1957) z. 2, 123-143; Problemy pokutne w I Liście św. Klemensa do Koryntian, RTK 3(1956) z. 2, 395-401; Pokuta kościelna w starożytności chrześcijańskiej. Świadectwo św. Dionizego z Aleksandrii, AK 49(1957) t. 54, 277-278.

${ }^{50}$ Por. J. Dudziak, Praktyka kanonizowania świętych przed ogłoszeniem dekretów papieża Grzegorza IX, TST 7(1979) 105-127; Teologiczno-prawne idee kanonów synodu w Sardyce (343), TST 8(1981) 337-350; Zalążki ogólnokościelnej dyscypliny duchowieństwa $w$ świetle postanowień I Soboru Nicejskiego (325), VoxP 7(1987) t. 12-13, 107-124.

${ }^{51}$ Por. J. Królikowski, Duchowość maryjna u Ojców Kościoła, VoxP 11-12(1991-1992) t. 2023, 548-552; Synteza tradycji chrześcijańskich. Cechy charakterystyczne ekumenizmu św. Ambrozego, VoxP 18(1998) t. 34-35, 107-118.

52 Por. A. Paciorek, Aktualność egzegezy patrystycznej, TST 8(1981) 307-312; Kościót lokalny w nauczaniu starożytnych pisarzy chrześcijańskich, TST 10(1987) 228-233; Egzegeza IV Ewangelii w pismach ojców Apostolskich, VoxP 8(1988) z. 12-13, 325-336; Święty Augustyn jako egzegeta, TST 12(1993) 175-190; Ambrozjańskie inspiracje egzegezy biblijnej, VoxP 18(1998) t. 34-35, 95-105 i inne.

53 Por. A. Drożdż, Ethos męczeństwa $i$,non violence” w II stuleciu chrześcijaństwa, VoxP 7(1987) t. 12-13, 87-106; Poszukiwanie mądrości a nawrócenie wedtug św. Augustyna. Aspekt epistemologiczno-etyczny, VoxP 8(1988) t. 14, 81-100. 
szcza w ostatnich latach, inspiratorem wielu z tych prac okazał się ks. S. Longosz, twórca i redaktor „Vox Patrum”. Artykuły ukazujące się na łamach tego czasopisma, a także udział niektórych księży tarnowskich w sympozjach i spotkaniach patrystycznych, to głównie jego zasługa ${ }^{54}$.

Dla pełni obrazu należy wspomnieć, że kilku następnych księży, którzy wprawdzie specjalizacje zdobywali na innych kierunkach, pisali wcześniej prace magisterskie $\mathrm{z}$ patrologii ${ }^{55}$. Można o nich powiedzieć, że podstawowa ich formacja intelektualna ma rys patrystyczny, co owocuje w dalszej działalności naukowo-dydaktycznej.

5. Szersze środowisko patrystyczne w Tarnowie. Można wskazać jeszcze na jeden wymiar w tym patrystycznym obliczu środowiska tarnowskiego. Nie ulega wątpliwości, że ten region ma coś, co można nazwać „atmosferą patrystyczną". Tworzą ją różne elementy. Do nich zaliczyć można liczną plejadę osób pochodzących z tego regionu i dobrze zapisujących się w badaniach i propagowaniu myśli Ojców Kościoła, czy też antyku chrześcijańskiego. Tu urodzili się i w szkołach tego regionu zdobywali swoje kwalifikacje: J. Sajdak $^{56}$, H. Kupiszewski ${ }^{57}$, T. Sinko ${ }^{58}$. Spośród współczesnych patrologów nie sposób pominąć ks. E. Stanulę, O. Ryznara (tłumacza kilku tomów PSP), czy ks. S. Longosza.

Środowisko teologiczne ze swej strony jest od dość dawna otwarte na inspiracje patrystyczne. Świadectwem tego są wyżej przedstawione przykłady. Do tego należy dodać także inne fakty, nieco mniejszej rangi, do których można zaliczyć znaczne zainteresowanie pismami Ojców Kościoła. Dowodzi tego popularność tych dzieł tak w okresie przedwojennym ${ }^{59}$, jak też później-

${ }^{54}$ Na łamach „Vox Patrum” ukazało się także kilka pojedynczych publikacji księży tutaj nie wymienionych. Świadczą one przede wszystkim o zainteresowaniu problematyką patrystyczną w środowisku tarnowskim. Ich promocja to już zasługa ks. S. Longosza. Wśród tych autorów można wymienić: ks. mgra Z. Ćwika, ks. dra K. Machetę, ks. mgra L. Stręka.

55 Por. ks. dr M. Zając (mgr 1985: Ideat chrześcijanina w „De officiis ministrorum” św. Ambrożego); ks. lic. S. Garnczarski (mgr 1987: Mariologia hymnu „Akathistos”); ks. dr J. Gębarowski (mgr 1987: Św. Piotr Chryzolog i jego mowy wybrane. Wstęp, przektad, komentarz); ks. dr A. Nita (mgr 1991: Patrystyczny wymiar katechetycznej twórczości ks. Władysława Budzika. Studium patrystyczno-katechetyczne).

${ }^{56}$ Urodził się w 1882 roku w Burzynie pod Tarnowem. Ukończył I Gimnazjum w Tarnowie w 1904 roku. W tym regionie często przebywał i na niego oddziaływał. W czasie wojny przebywał w klasztorze OO. Redemptorystów w Tuchowie, korzystając z ich biblioteki i kontynuując swoje prace nad Ojcami Kościoła. Wtedy m.in. powstała jego praca: K.S.F. Tertulian. Czasy - życie dzieto, Poznań 1949. Współpracował z ks. J. Czujem i inspirował do pracy translatorskiej ks. W. Kanię.

${ }^{57}$ Urodzony w Łężkowicach, gimnazjum ukończył w Bochni.

58 T. Sinko urodził się 14.09.1877 w Małej k. Ropczyc.

${ }^{59} \mathrm{~W}$ okresie przedwojennym na ok. 150 prenumeratorów POK, co najmniej 10 pochodzilo z diecezji tarnowskiej. 
szym. Ilość publikacji, jakie ukazały się w tym środowisku może imponować ${ }^{60}$. Autorzy tworzący tarnowskie środowisko patrystyczne tworzyli dzieła o różnym charakterze. Największe zasługi położyli autorzy zajmujący się pracą translatorską, zwłaszcza ks. J. Czuj, ks. W. Kania, ks. W. Budzik. Nie brak tam także prac koncepcyjnych i popularyzatorskich. Trudno tu nakreślić jakąś ścisłą ich charakterystykę. Z całą pewnością większym zainteresowaniem cieszyły się zagadnienia związane $\mathrm{z}$ historią duchowości i instytucji. Mniejsze osiągnięcia odnotowano w badaniach i popularyzowaniu zagadnień doktrynalnych, choć ostatnio i w tej dziedzinie zauważyć można dość interesujące tendencje.

Z całą pewnością nie jest to pełny wkład środowiska tarnowskiego w polską patrologię. Zostały tu przedstawione tylko uchwytne faktory składające się na ten dorobek. Jest on na tyle pokaźny, że można mówić o pewnej tradycji, a jednocześnie zobowiązujący do dalszego rozwijania. Jak na dzisiaj perspektywy są w miarę optymistyczne.

\section{IL CONTRIBUTO DELL'AMBIENTE TEOLOGICO DI TARNÓW NELLA RICERCA SULLA ANTICHITÀ CRISTIANA.}

(Riassunto)

L'argomento presentato in questo articolo comprende alcuni dati che fanno vedere la storia della patrologia nell'Istituto Teologico di Tarnów e le figure dei più pretigiosi patrologi legati con l'ambiente teologico di Tarnów. Le tradizioni patristiche a Tarnów risalgono all'inizio dell'Istituto Teologico. Dello sviluppo si può parlare dopo la guerra, da quando ha cominciato insegnare il prof. W. Kania. Sotto la sua direzione tanti seminaristi hanno studiato la patrologia. Il prof. W. Kania e prima di lui il prof. J. Czuj appartengono ai più grandi patrologi polacchi del XX secolo. Interessante era anche una iniziativa, malgrado falita, di creare un Istituto Patristico a Tarnów. Oggi le tradizioni patristiche a Tarnów vengono sviluppati grazie ad assai grande numero dei teologi dediti a questi studi.

${ }^{60}$ Do najważniejszych zaliczyć należy publikacje w ramach TST. Dwa tomy (I i VIII) zostały w pełni poświęcone tej problematyce, a w innych publikacje patrystyczne są stale obecne. Często publikacje o charakterze patrystycznym ukazują się na łamach pisma urzędowego „Currenda”. Ukazywały się tam zarówno krótsze teksty, jak też opracowania. W diecezjalnym wydawnictwie „Biblos” ukazało się kilka pozycji patrystycznych (Ks. M. Starowieyski, Sobory Kościoła niepodzielonego. Częśc I - dzieje, Tarnów 1994; A.M. Malingrey, Chrześcijańska literatura grecka, Tarnów 1995; J. Fontaine, Chrześcijańska literatura tacińska, Tarnów 1997; W. Kania, Świadkowie Tradycji, Tarnów 1998; ks. A. Żurek, Wprowadzenie do Ojców Kościoła, Tarnów 1998²; tenże, Pierwsze wieki Kościoła (I-VII wiek), Tarnów 2000. 


\section{WYKAZ PRAC DYPLOMOWYCH NAPISANYCH W INSTYTUCIE TEOLOGICZNYM W TARNOWIE \\ (chronologicznie)}

1. F. Górka, Nauka św. Grzegorza z Nyssy o modlitwie, pr. dypl., prom. ks. dr W. Kania, Tarnów 1967.

2. K. Pres, Zagadnienie cierpliwości u św. Cypriana, pr. dypl., prom. ks. dr W. Kania, Tarnów 1968.

3. S. Świderski, Modlitwa Pańska u św. Cypriana. Studium patrystyczno-biblijne, pr. dypl., prom. ks. dr W. Kania, Tarnów 1968.

4. J. Trela, Charytatywna działalność papieża Grzegorza W. w świetle jego listów, pr. dypl., prom. ks. dr W. Kania, Tarnów 1968.

5. J. Majerski, Zagadnienie modlitwy u Tertuliana, pr. dypl., prom. ks. dr W. Kania, Tarnów 1969.

6. J. Michalik, Interpretacja wypowiedzi św. Bazylego W. z 27 rozdz. rozprawy „O Duchu Świętym”, pr. dypl., prom. ks. dr W. Kania, Tarnów 1969.

7. E. Gabryel, „Chleba naszego powszedniego daj nam dzisiaj” - czwarta prośba Modlitwy Pańskiej w świetle egzegezy katolickiej ze szczególnym uwzględnieniem Ojców Kościoła, pr. dypl., prom. ks. lic. W. Gnutek, Tarnów 1970.

8. M. Czech, Św. Cyryl Aleksandryjski w świetle encykliki papieża Piusa XII „Ozdoba Kościoła Wschodniego”, pr. dypl., prom. ks. dr W. Kania, Tarnów 1971.

9. A. Gieroń, Zagadnienie jedności Kościoła u papieża Leona Wielkiego, pr. dypl., prom. ks. dr W. Kania, Tarnów 1971.

10. R. Rak, Ideat kapłana wg św. Hieronima, pr. dypl., prom. ks. dr W. Kania, Tarnów 1971.

11. Z. Zych, Droga do doskonałości wg Jana Kasjana, pr. dypl., prom. ks. dr W. Kania, Tarnów 1971.

12. S. Budyn, Modlitwa powszechna u Ojców Kościoła (I-VI wiek) $i$ w liturgiach wschodnich, pr. dypl., prom. ks. dr P. Gajda, Tarnów 1971.

13. J. Chlebek, Znak zwycięstwa, pr. dypl., prom. ks. dr P. Gajda, Tarnów 1971.

14. J. Nalepa, Inicjacja chrześcijańska u świętego Cyryla Jerozolimskiego, pr. mgr., prom. ks. dr W. Kania, Tarnów 1972.

15. Cz. Szewczyk, Nauka Orygenesa o modlitwie, pr. dypl., prom. ks. dr W. Kania, Tarnów 1972.

16. J. Bukowski, Nauka Tertuliana o modlitwie. Studium ascetyczno-patrystyczne, pr. dypl., prom. ks. dr W. Kania, Tarnów 1973.

17. J. Bylinowski, Życie pierwotnej gminy chrześcijańskiej w świetle „Tradycji Apostolskiej" św. Hipolita, pr. dypl., prom. ks. dr W. Kania, Tarnów 1973.

18. A. Gurgul, Życie samotne źródtem szczęścia w ujęciu św. Jana Chryzostoma, pr. dypl., prom. ks. dr W. Kania, Tarnów 1973.

19. S. Marczewski, Życie chrześcijan u progu Kościoła w świetle „Nauki dwunastu Apostołów”, pr. dypl., prom. ks. dr W. Kania, Tarnów 1973. 
20. S. Borek, Liturgia Mszy św. IV-go wieku w opisie św. Cyryla Jerozolimskiego, pr. dypl., prom. ks. dr W. Kania, Tarnów 1974.

21. A. Iżyk, Eucharystia w pieśniach Cyryllonasa, pr. dypl., prom. ks. dr W. Kania, Tarnów 1974.

22. J. Marecik, Zagadnienie cierpliwości u Tertuliana, pr. dypl., prom. ks. dr W. Kania, Tarnów 1974.

23. S. Gancarz, Konstantyn Wielki $i$ jego prawodawstwo dla Kościoła, pr. dypl., prom. ks. dr W. Węgiel, Tarnów 1974.

24. J. Dominik, Nauka Tertuliana o chrzcie, pr. dypl., prom. ks. dr W. Kania, Tarnów 1975.

25. Cz. Frączek, Pierwsze kazanie prymicyjne. Studium patrystyczno-homiletyczne, pr. dypl., prom. ks. dr W. Kania, Tarnów 1975.

26. W. Książko, Poglądy Tertuliana na widowiska, pr. dypl., prom. ks. dr W. Kania, Tarnów 1975.

27. A. Lorczyk, Idee teologiczne hymnu liturgicznego św. Efrema „O Maryi i mędrcach”, pr. dypl., prom. ks. dr W. Kania, Tarnów 1975.

28. S. Skowron, Interpretacja Genesis 1,1 u św. Jana Chryzostoma, pr. dypl., prom. ks. dr W. Kania, Tarnów 1975.

29. A. Potoniec, Nauka Cyryla Jerozolimskiego o Duchu Świętym, pr. dypl., prom. ks. dr W. Kania, Tarnów 1976.

30. S. Wdowiak, Nauka Jana Chryzostoma o Duchu Świętym, pr. dypl., prom. ks. dr W. Kania, Tarnów 1976.

31. S. Żurat, Ideat kapłana wg św. Grzegorza W. w świetle „Księgi reguty pasterskiej”, pr. dypl., prom. ks. dr W. Kania, Tarnów 1977.

32. A. Dźwigaj, Prymat biskupa rzymskiego w świetle listu św. Klemensa Rzymskiego do Koryntian, pr. mgr., prom. ks dr hab. W. Kania, Tarnów 1979.

33. S. Saładyga, Zagadnienie Modlitwy Pańskiej u św. Augustyna, ze szczególnym uwzględnieniem problemów egzegetycznych, pr. dypl., prom. ks. dr hab. W. Kania, Tarnów 1978.

34. S. Adamczyk, Struktura mów żatobnych św. Grzegorza z Nyssy, pr. mgr., prom. ks. dr hab. W. Kania, Tarnów 1980.

35. M. Kurnyta, Nauka św. Ignacego Antiocheńskiego o jedności Kościoła, pr. dypl., prom. ks. dr hab. W. Kania, Tarnów 1980.

36. S. Pałka, Św. Jan Ztotousty jako nauczyciel chrześcijańskiego wychowania dzieci i młodzieży, pr. dypl., prom. ks. dr W. Kania, Tarnów 1980.

37. Cz. Kaput, Interpretacja Modlitwy Pańskiej u Orygenesa, pr. dypl., prom. ks. dr hab. W. Kania, Tarnów 1981.

38. M. Klimek, Ideat kapłana wg świętego Grzegorza z Nazjanzu, pr. dypl., prom. ks. dr hab. W. Kania, Tarnów 1981.

39. J. Nowak, Inicjacja chrześcijańska u św. Cyryla Jerozolimskiego, pr. dypl., prom. ks. dr hab. W. Kania, Tarnów 1982.

40. R. Bojdo, Aurelius Augustinus „De moribus Ecclesiae Catholice”. Wstęp, tłumaczenie, komentarz, pr. dypl., prom. ks. dr E. Łomnicki, Tarnów 1983.

41. E. Mikoś, Jedność Kościoła w postudze pasterskiej św. Bazylego W., pr. dypl., 
prom. ks. dr hab. W. Kania, Tarnów 1983.

42. L. Stręk, Ideat kaptana wg św. Efrema (studium patrystyczne), pr. mgr., prom. ks. dr hab. W. Kania, Tarnów 1983.

43. T. Wiszniewski, Idea dziewictwa u św. Hieronima, pr. mgr., prom. ks. dr hab. W. Kania, Tarnów 1983.

44. S. Wojdak, Rodzina w nauce św. Ambrożego, pr. mgr., prom. ks. dr hab. W. Kania, Tarnów 1983.

45. K. Piekarski, Jezus Chrystus w ujęciu Orygenesa - „Contra Celsum”, pr. dypl., prom. ks. dr S. Rosa, Tarnów 1983.

46. J. Serwoński, Q.S.F. Tertulian, $O$ ciele Chrystusa, pr. mgr., prom. ks. dr E. Łomnicki, Tarnów 1983.

47. M. Łopatka, Motywy wiarygodności chrześcijaństwa w „Przeciw Celsusowi” Orygenesa , pr. dypl., prom. ks. dr E. Łomnicki, Tarnów 1983.

48. M. Kiełbasa, Problematyka Objawienia w pismach dogmatycznych i egzegetycznych św. Ambrożego, pr. dypl., prom. ks. dr E. Łomnicki, Tarnów 1983.

49. M. Hołowicki, S. Ambrosii Mediolanensis Episcopi „De Jacob et vita beata”. Wstęp, tłumaczenie, komentarz, pr. dypl., prom. ks. dr E. Łomnicki, Tarnów 1984.

50. S. Michalik, K.S.F. Tertulian „O wstydliwości”, pr. dypl., prom. ks. dr E. Łomnicki, Tarnów 1984.

51. S. Piszczek, Myśl spoteczna Klemensa Aleksandryjskiego, pr. mgr., prom. ks. dr hab. W. Kania, Tarnów 1984.

52. T. Rzeźnik, Obrońca tytutu Theotokos - św. Cyryl Aleksandryjski, pr. dypl., prom. ks. dr hab. W. Kania, Tarnów 1984.

53. J. Gajda, S. Aurelius Augustinus „De sancta virginitate”. Wstęp, ttumaczenie, komentarz, pr. mgr., prom. ks. dr E. Łomnicki, Tarnów 1985.

54. M. Zając, Ideał chrześcijanina w „De officiis ministrorum” św. Ambrożego, pr. mgr., prom. ks. dr hab. W. Kania, Tarnów 1985.

55. J. Gawle, Św. Aureliusz Augustyn-O kłamstwie. Wstęp, thumaczenie, komentarz, pr. dypl., prom. ks. dr E. Łomnicki, Tarnów 1985.

56. E. Myszkowski, Nauka Tertuliana o duszy, pr. dypl., prom. ks. dr hab. W. Kania, Tarnów 1986.

57. A. Sawina, Wybór mów św. Piotra Chryzologa. Wstęp, ttumaczenie, komentarz, pr. mgr., prom. ks. dr E. Łomnicki, Tarnów 1986.

58. K. Nawalaniec, Idea Boga w katechezach św. Cyryla Jerozolimskiego, pr. dypl., prom. ks. dr hab. W. Kania, Tarnów 1986.

59. W. Ochalik, Nauka św. Jana Chryzostoma o modlitwie, pr. dypl., prom. ks. dr hab. W. Kania, Tarnów 1986.

60. P. Fałowski, Idee teologiczne „Pieśni” Balaja z okazji poświęcenia kościoła w Kenneszrin, pr. mgr., prom. ks. dr hab. W. Kania, Tarnów 1987.

61. S. Garnczarski, Mariologia hymnu „Akathistos”, pr. mgr., prom. ks. dr hab. W. Kania, Tarnów 1987. .

62. J. Gębarowski, Św. Piotr Chryzolog „Mowy wybrane”. Wstęp, thumaczenie, komentarz, pr. mgr., prom. ks dr E. Łomnicki, Tarnów 1987. 
63. Cz. Paszyński, Elementy homiletyczne u św. Piotra Chryzologa. Studium patrystyczno-homiletyczne, pr. mgr., prom. ks. dr hab. W. Kania, Tarnów 1988.

64. P. Góra, Św. Piotr Chryzolog, Mowy wybrane. Wstęp, ttumaczenie, pr. mgr., prom., ks. dr E. Łomnicki, Tarnów 1988.

65. J. Gubernat, Sanctus Aurelius Augustinus - Ad Catholicos contra Donatistas Epistula, sive de unitate Ecclesiae, pr. mgr., prom. ks. dr E. Łomnicki, Tarnów 1988.

66. A. Bąk, Mariologia uśw. Ildefonsa z Toledo, pr. dypl., prom. ks. dr hab. W. Kania, Tarnów 1989.

67. R. Filipowicz, Życie pierwotnej gminy chrześcijańskiej w listach św. Ignacego Antiocheńskiego, pr. mgr., prom. ks. dr hab. W. Kania, Tarnów 1989.

68. J. Masłoń, Nauka Atenagorasa z Aten o Bogu, pr. mgr., prom. ks. dr hab. W. Kania, Tarnów 1989.

69. M. Wojnarowski, Zmartwychwstanie umartych w nauce Atenagorasa $z$ Aten, pr. mgr., prom. ks. dr hab. W. Kania, Tarnów 1989.

70. J. Kurcap, Sanctus Ambrosius „De viduis”, pr. mgr., prom. ks. dr E. Łomnicki, Tarnów 1989.

71. A. Pawlik, Sanctus Hilarius - Tractatus de mysteriis. Wstęp, przekład, komentarz, pr. mgr., prom. ks. dr E. Łomnicki, Tarnów 1990.

72. B. Więcek, S. Ambrosius „De Joseph patriarcha”. Wstęp, tłumaczenie, pr. mgr., prom. ks. dr E. Łomnicki, Tarnów 1990.

73. S. Góral, Ideat mówcy kościelnego wg św. Augustyna, pr. dypl., prom. ks. dr hab. W. Kania, Tarnów 1990.

74. P. Lis, Katecheza św. Efrema, pr. dypl., prom. ks. dr hab. W. Kania, Tarnów 1990.

75. P. Witecki, Problematyka moralna w katechezach chrzcielnych św. Jana Chryzostoma, pr. mgr., prom. ks. dr W. Kania, Tarnów 1990.

76. A. Nita, Patrystyczny wymiar katechetycznej twórczości ks. Wt. Budzika. Studium patrystyczno-katechetyczne, pr. mgr., prom. ks. dr hab. W. Kania, Tarnów 1991.

77. S. Oleksyk, Katecheza Cyryllonasa, pr. dypl., prom. ks. dr hab. W. Kania, Tarnów 1991.

78. S. Piszczek, Stosunek chrześcijanina do dóbr materialnych wg Klemensa Aleksandryjskiego, pr. mgr., prom. ks. dr hab. W. Kania, Tarnów 1991.

79. B. Połeć, Patrystyczny wymiar homiletycznej twórczości ks. Jana Czuja. Studium patrystyczno-homiletyczne, pr. mgr., prom. ks. dr hab. W. Kania, Tarnów 1991.

80. R. Biernat, Sanctus Augustinus „, Contra Sermonem Arianorum”. Wstep, thumaczenie, komentarz, pr. mgr., prom. ks. E. Łomnicki, Tarnów 1991.

81. R. Góra, Św. Ambroży „De Tobia”. Wstęp, tłumaczenie, pr. mgr., prom. ks. dr E. Łomnicki, Tarnów 1991.

82. T. Majchrzak, Ambrozjaster, Commentaria in epistulam ad Ephesios. Wstęp, thumaczenie, pr. mgr., prom. ks. dr E. Łomnicki, Tarnów 1991.

83. L. Durlak, Kapłaństwo w listach Hieronima, pr. mgr., prom. ks. dr A. Żurek, Tarnów 1992.

84. A. Gadzina, Grzegorz z Nazjanzu w świetle swoich listów, pr. mgr., prom. ks. dr hab. W. Kania, Tarnów 1992.

85. P. Kisiel, Eschatologia w nauczaniu katechetycznym Augustyna na podstawie 
„Podręcznika do Wawrzyńca, czyli o wierze, nadziei i miłości”, pr. mgr., prom. ks. dr A. Żurek, Tarnów 1992.

86. R. Serafin, Elementy homiletyczne u św. Grzegorza z Nazjanzu, pr. mgr., prom. ks. dr hab. W. Kania, Tarnów 1992.

87. P. Bodziony, Modlitwa Pańska u Teodora z Mopswestii, pr. mgr., prom. ks. dr hab. W. Kania, Tarnów 1993.

88. Z. Frączek, Pokój u św. Grzegorza z Nazjanzu w oparciu o jego trzy Mowy o pokoju, pr. mgr., prom. ks. dr hab. W. Kania, Tarnów 1993.

89. J. Jackowski, Laikat w kościele poapostolskim na podstawie: „Didache”, „Listów” "św. Ignacego Antiocheńskiego i „Listu” św. Polikarpa, pr. mgr., prom., ks. dr A. Żurek, Tarnów 1993.

90. M. Piec, Ideał człowieka w pasterskiej postudze św. Grzegorza z Nazjanzu, pr. mgr., prom. ks. dr W. Kania, Tarnów 1993.

91. W. Sroka, Maryjne oblicze św. Efrema, pr. mgr., prom. ks. dr hab. W. Kania, Tarnów 1993.

92. S. Stasiak, Gtówne tematy mariologiczne w „Protoewangelii Jakuba”, pr. mgr., prom. ks. dr A. Żurek, Tarnów 1993.

93. T. Wolak, Oblicze maryjne św. Germana z Konstantynopola. Studium patrystyczne, pr. mgr., prom. ks. dr hab. W. Kania, Tarnów 1993.

94. A. Cebulski, Powołanie kapłańskie na podstawie „Księgi reguty pasterskiej” Grzegorza Wielkiego, pr. mgr., prom. ks. dr A. Żurek, Tarnów 1994.

95. K. Ligęza, Ideat katechety według Jana Chryzostoma, pr. mgr., prom. ks. dr hab. W. Kania, Tarnów 1994.

96. J. Węgrzyn, Sylwetka duchowa św. Bazylego na tle jego listów, pr. mgr., prom. ks. dr hab. W. Kania, Tarnów 1994.

97. W. Paterak, Modlitwa, post $i$ jatmużna a oczyszczenie serca, na podstawie „De sermone Domini in Monte" św. Augustyna, pr. mgr., prom. ks. dr A. Żurek, Tarnów 1994.

98. M. Szteliga, Wspólnota Ojców Jurajskich i jej duchowość, pr. dypl., prom. ks. A. Żurek, Tarnów 1994.

99. M. Jachymczak, Miłosierdzie u św. Cypriana, pr. mgr., prom. ks. dr A. Żurek, Tarnów 1995.

100. G. Sowa, Gmina chrześcijańska w Kartaginie na podstawie listów św. Cypriana, pr. mgr., prom. ks. dr A. Żurek, Tarnów 1995.

101. S. Szufnara, Interpretacja Modlitwy Pańskiej u Tertuliana, pr. mgr., prom. ks. dr hab. W. Kania, Tarnów 1995.

102. T. Paluch, Teologia i mariologia perykopy o zwiastowaniu u Orygenesa, pr. mgr. prom. ks. dr A. Żurek, Tarnów 1996.

103. K. Prokop, Chrystologia i soteriologia Jana Chryzostoma $w$ homiliach na listy pasterskie św. Pawła, pr. mgr., prom. ks. dr. A. Żurek, Tarnów 1996.

104. J. Otfinowski, Wychowanie w nauczaniu św. Jana Chryzostoma, pr. mgr., prom. ks. dr S. Sojka, Tarnów 1996.

105. J. Bodziony, Człowiek wedtug traktatu „O zasadach” Orygenesa, pr. mgr., prom. ks. dr A. Żurek, Tarnów 1997. 
106. B. Mądro, Modlitwa w pismach św. Grzegorza Wielkiego, pr. mgr., prom. ks. dr S. Sojka, Tarnów 1997.

107. A. Mgłosiek, Bóg wiary uśw. Augustyna, pr. mgr., prom. ks. dr S. Sojka, Tarnów 1997.

108. L. Niemiec, Biblia w nauczaniu św. Augustyna, pr. mgr., prom. ks. dr S. Sojka, Tarnów 1997.

109. M. Pichla, Humanitas w pismach św. Grzegorza Wielkiego, pr. mgr., prom. ks. dr S. Sojka, Tarnów 1997.

110. A. Pacocha, Modlitwa w pismach św. Grzegorza z Nyssy, pr. mgr., prom. ks. dr S. Sojka, Tarnów 1997.

111. W. Wojnarowski, Chrystus jedyny Zbawiciel świata i Pan historii uśw. Augustyna, pr. mgr., prom. ks. dr S. Sojka, Tarnów 1997.

112. E. Ruszel, Grzegorz Wielki papieżem pokoju, pr. mgr., prom. ks. dr S. Sojka, Tarnów 1997.

113. D. Kopeć, Grzegorz Wielki w stużbie dobra i sprawiedliwości w świetle listów, pr. mgr., prom. ks. dr S. Sojka, Tarnów 1997.

114. E. Myszkowski, Doktryna o duszy w katechetycznym wykładzie Tertuliana, pr. mgr., prom. ks. A. Solak, Tarnów 1997.

115. D. Ciosek, Perykopa o chrzcie Jezusa (J 1, 29-34) we wspótczesnej i patrystycznej egzegezie, pr. mgr, prom. ks. dr hab. A. Paciorek, Tarnów 1997.

116. T. Rzeźnik, Obronca tytułu ,Theotokos” - św. Cyryl Aleksandryjski, pr. mgr., prom. ks. dr hab. W. Kania, Tarnów 1997.

117. A. Trepa, Teatr w epoce wczesnochrześcijańskiej, pr. mgr., prom. ks. dr S. Sojka, Tarnów 1998.

118. D. Mytych, Problematyka matżeńska na synodach w Elwira i Arles, pr. mgr., prom. ks. dr A. Żurek, Tarnów 1998.

119. L. Potępa, Maryja w świetle apokryfów o narodzeniu i dzieciństwie, pr. mgr., prom. ks. dr hab. A. Żurek, Tarnów 1998.

120. P. Cyz, Specyfika i sens ascezy syryjskich Ojców Pustyni w świetle „Dziejów miłości Bożej” Teodoreta z Cyru, pr. mgr, prom. ks. dr hab. A. Żurek, Tarnów 1999.

121. C.M. Onze, Les problèmes de la Trinité au IV siécle. Controverse de saint Basile et Eunome, pr. mgr., prom. ks. dr hab. A. Zurek, Tarnów 1999.

122. J. Gawle, Św. Augustyna „O kłamstwie”. Wstęp i przekład, pr. mgr., prom. ks. dr hab. A. Zurek, Tarnów 1999.

123. A. Wojtusik-Pabian, Problematyka dydaktyczno-pedagogiczna $w$ wybranych pismach św. Augustyna, pr. mgr., prom. ks. dr A. Solak, Tarnów 1999.

124. B. Jarek, Ideat wychowania w świetle „De catechizandis rudibus” św. Augustyna, pr. mgr., prom. ks. dr S. Sojka.

\section{Licencjaty:}

1. B. Połeć, Aspekt mariologiczny w pismach św. Bedy Czcigodnego, prom. ks. dr hab. W. Kania, Tarnów 1995. 